\title{
Open educational resources (OER) in the Spanish universities
}

\author{
Gema Santos-Hermosa; Eva Estupinyà; Brigit Nonó-Rius; Lidón París-Folch; Jordi \\ Prats-Prat
}

Nota: Este artículo se puede leer en español en:

https://profesionaldelainformacion.com/contenidos/2020/nov/santos-estupinya-nono-paris-prats_es.pdf

How to cite this article:

Santos-Hermosa, Gema; Estupinyà, Eva; Nonó-Rius, Brigit; París-Folch, Lidón; Prats-Prat, Jordi (2020). “Open educational resources (OER) in the Spanish universities". Profesional de la información, v. 29, n. 6, e290637. https://doi.org/10.3145/epi.2020.nov.37

Manuscript received on $30^{\text {th }}$ Juny 2020 Accepted on $31^{\text {th }}$ August 2020
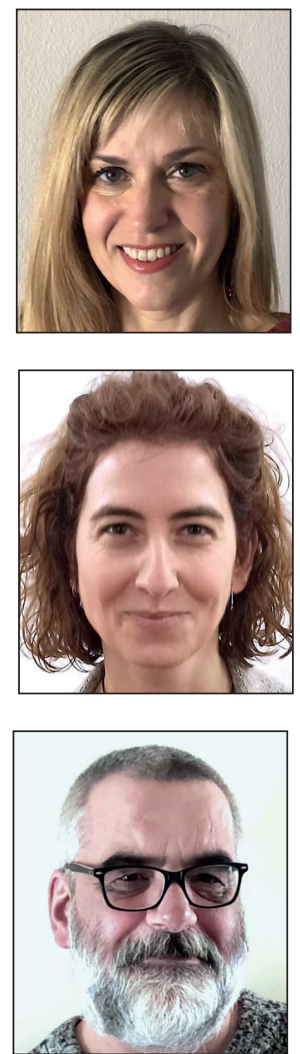

Gema Santos-Hermosa $\triangle$ https://orcid.org/0000-0002-2776-871X

Universitat de Barcelona

Facultat d'Informació i Mitjans

Audiovisuals

Melcior de Palau, 140

08014 Barcelona, Spain

gsantos@ub.edu

\section{Brigit Nonó-Rius}

https://orcid.org/0000-0001-9933-370X

Universitat de Girona

Biblioteca, Serveis tècnics.

Maria Aurèlia Capmany i Farnés, 67

17003 Girona, Spain

brigit.nono@udg.edu

\section{Jordi Prats-Prats}

https://orcid.org/0000-0002-6958-5575

Universitat Politècnica de Catalunya

Servei de Biblioteques, Publicacions i Arxius

Jordi Girona, 1-3

08034 Barcelona, Spain

jordi.prats@upc.edu

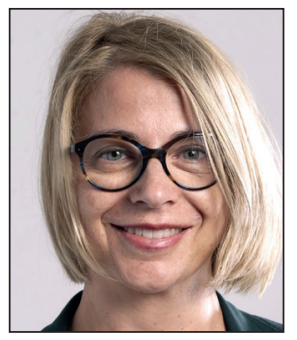

Eva Estupinyà

https://orcid.org/0000-0003-2051-7288

Universitat de Lleida

Servei de Biblioteca i Documentació

Carrer de Jaume II, 67. 25001 Lleida, Spain

eva.estupinya@udl.cat

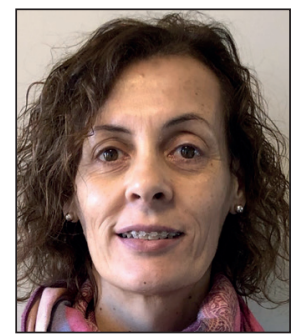

Lidón París-Folch

https://orcid.org/0000-0002-1708-0356

Universitat Jaume I

Biblioteca

Av. Vicent Sos Baynat, $\mathrm{s} / \mathrm{n}$

12071 Castelló de la Plana, Spain

paris@uji.es

\begin{abstract}
Open educational resources (OERs) have become a key element in the development of quality education within the 2030 Agenda. This article discusses the current situation of OER in Spanish universities, analysing their publishing platforms, policies, strategies and incentives for authors. In addition, the characteristics of the existing OERs in institutional repositories are analysed and a proposal for development stages, according to their purpose and level of openness, is presented. This study concludes that, although there is growing interest in OER, there is currently no general awareness of what OER is or what its creation entails. Interdisciplinary cooperation of the professionals involved is, therefore, essential to create OER that can be found, shared and reused.
\end{abstract}

\section{Keywords}

Open educational resources; OER; Universities; Educational institutions; Institutional repositories; Educational innovation; Policies; Incentive; E-learning platforms; Ecosystem of services; OpenCourseWare; OCW. 
Funding

This study was carried out in the framework of line 3 of Rebiun (specifically action 6, within the repository workgroup) and the consolidated research group "Cultura i Continguts Digitals" (SGR 2017-422), financed by Agència de Gestió d'Ajuts Universitaris i de Recerca (Agaur) - Agency for Management of University and Research Grants) of Generalitat de Catalunya (the Government of Catalonia). It has also benefited from the collaboration of Guillem Cebrián.

\section{Introduction and background}

Over the last decade, open educational resources (OER) have developed considerably, almost becoming key elements in the process of transformation of higher education (Johnson et al., 2013). It is currently believed that OER can help create inclusive knowledge societies (Unesco, 2019) and to meet Sustainable Development Goal 4 (quality education) of the 2030 Agenda.

Educational institutions and digital repositories are two of the agents involved in the achievement of these objectives. Both are mentioned explicitly in the recommendations of the $40^{\text {th }}$ General conference of Unesco on OER, in which there is a call for greater participation of educational institutions and the harnessing of repositories and open standards to

"ensure that OER can be easily found, accessed, re-used, adapted and redistributed" (Unesco, 2019, p. 4).

Against this backdrop, universities are proposing a range of strategies to produce and disseminate OER content. Some of these include, for instance, creating educational innovation units or calls for innovation projects and improvements in teaching quality (Fernández-Pampillón-Cesteros; Domínguez-Romero; De-Armas-Ranero, 2013). Others turn to library support services (Rebiun, 2007) and to institutional repositories (IR) as means of communicating teaching knowledge generated within the universities.

For several years, repositories such as Merlot, OER Commons and Open Stax CNX have existed exclusively for educational resources. In Spain, apart from repositories arising from research projects on e-learning or national initiatives focused on education levels outside university (such as Agrega, etc.), few examples of educational repositories can be identified in the university context. The MDX (Materials docents en xarxa) repository by Catalonian universities and the OpenCourseWare initiative (OCW) are a few exceptions (Bueno-De-la-Fuente; Hernández-Pérez, 2011).

For this reason, and although the ideal solution would be technological infrastructures created exclusively for, and adapted to, the specifications of OER (Bueno-De-la-Fuente, 2010; Santos-Hermosa; Ferran-Ferrer; Abadal, 2017), at present, the common strategy in the Spanish university context is for OER to be stored and disseminated by IR and OCW, as well as on their own virtual campuses. They are, therefore, mixed repositories with teaching and research material. On this basis, the issues raised in this study, limited to the Spanish context, aim to delineate the current situation and the main characteristics of OER in universities and how they have adapted to platforms which were originally created for research materials.

An overview of higher education on an international scale reflects a similar situation: on one hand, there is greater availability of OER and OCW and, more recently (Cheung, 2020), on digital platforms specifically designed for open textbooks (BC Campus, Suny Open Texbooks, etc.). On the other hand, a growing number of universities have begun to consider IR as a principal point of access to OER produced by their academics and students. Some of the reasons for this revolve around the issue of preservation and versioning (Goodsett; Loomis; Miles, 2016; Ferguson, 2017).

Most of the previous literature analyses the situation and evolution of Spanish IRs with respect to research materials. During the expansion of the open access movement in Spain, it was important to know the number, type and growth patterns of the repositories (Melero, 2008). Later, indices were established for general (Serrano-Vicente; Melero; Abadal, 2018) and specific analysis about the content, deposit policies and access to research (Casal-Reyes et al., 2013). These studies make some exceptional references to educational resources, such as quantitative information about volume and percentage in relation to the total of objects (Melero et al., 2009; Barrueco et al., 2017).

There are other studies, with a greater focus on the analysis of the evolution of repositories with learning objects in Spain, between 2007 and 2012 (Rebiun, 2007; Santos-Hermosa; Ferran-Ferrer; Abadal, 2012; Fernández-PampiIlón-Cesteros; Domínguez-Romero; De-Armas-Ranero, 2013) and on establishing viable strategies for the success of educational content (Bueno-De-la-Fuente; Hernández-Pérez, 2011). The previous literature was also concerned with discovering the impact of Spanish OCW platforms, analysing the courses that they offer (Tovar, 2013). A more recent report (Rebiun, 2019) examines the state of OER in Spanish universities, producing some results about tools that facilitate access and some of the salient features.

Beyond the issues mentioned, there is a shortage of empirical evidence about the adoption and use of repositories with educational content (Rodés-Paragarino; Gewerc-Barujel; Llamas-Nistal, 2015). To this end, our study aims to offer a detailed overview of the educational resources in the Spanish university context. On one hand, the aim is to provide answers regarding publication platforms, promotion policies and incentives for authors; on the other hand, to analyse teaching material collections from IRs and the intrinsic characteristics of resources deposited in them, in order to, ultimately, establish a proposal for stages of development. 


\section{Objectives and methodology}

The main purpose of this study is to analyse OER in the Spanish university context, based on the member institutions of Rebiun (Red de Bibliotecas Universitarias Españolas) (Spanish University Libraries Network) and paying special attention to the nature of educational resources, promotion policies and incentives, as well as platforms that facilitate access to them (repositories).

Questions (or specific objectives) of this research are:

O1. Which OER publication platforms are present in Spanish universities and what is the nature of the co-existence between them?

O2. What is the impact of OER policies?

O3. What incentives or recognition for OER authors are present in Spanish universities?

O4. What are the OER of teaching communities/collections in Spanish repositories like: salient features?

O5. How can these repositories be classified in relation to the stage of development of their teaching collections and deposited OER?

In order to answer these research questions, a mixed method investigation has been carried out, combining two research techniques: a survey (González-Teruel, 2005) and content analysis (Krippendorff, 2013).

\subsection{Survey}

The baseline survey for this study is the online questionnaire entitled "Recursos educativos en acceso abierto en las universidades españolas" (Open access educational resources in Spanish universities), distributed in 2018 among 76 Rebiun institutions and obtaining a total of 53 responses (70\% of members) (Rebiun, 2019).

\section{Open educational resources (OER) have developed considerably, almost beco- ming key elements in the process of transformation of higher education}

The study at hand goes further: it does not focus on the entire survey, but instead performs an in-depth analysis only on the questions which relate directly to the research objectives.

Moreover, a more in-depth analysis is carried out, by cross referencing the data from some of these questions. However, by cross referencing, it is not intended to establish dependency correlations between numerical variables, nor to identify whether changes in one variable can influence another, but rather to bring to light possible behaviours or patterns among related aspects that can be confirmed in the future in a systematic way.

The original survey is composed of 15 questions, which make reference to the institutional context of educational resources (policies and strategies, relevant units and services used for their management, types of authorship and incentives), publication platforms (internal and external, deposit procedures, metadata standards, interoperability), and their characteristics.

Below is detailed which survey questions (and cross-referencing of questions) have been analysed (using the nomenclature "P_value": $P$ = question and value = question number) in relation to the first three objectives $(01,02$ and 03$)$ of this investigation.

01: OER publication platforms and co-existence between them

P_1: Does your university have any publication system for educational resources?

P_2: In what other environments external to the institution are educational resources created within the institution shared?

Cross P_1 and P_2

O2: Impact of OER policies

P_3 Does your university have an open access policy?

P_3b (if answer is positive): Does your open access policy include the recommendation/obligation to publish OER?

P_4 Does your university have a specific policy for open educational resources?

P_5 Although your institution does not have a specific policy for open educational resources, do you know of any strategy or action plan that is being worked on?

P_8 What sort of open licences are used for educational resources? Cross references: P3-P3b, P3-P4, P3-P5 and P3-P8.

O3: Incentives

P_9 Does your university plan incentives or recognition for authors who publish OER?

P_10 Can you indicate the nature of the recognition or incentives mentioned?

Cross-reference P_9 and P_10 


\subsection{Content analysis}

The content analysis was conducted from the Rebiun directory of institutional repositories of which, currently, has 76 repositories (belonging to 67 member institutions and 1 associate member).

https://www.rebiun.org/directorio-repositorios-institucionales

An initial analysis was carried out, determining that 45 IRs have teaching communities. Once this population was established, each repository was accessed in order to perform content analysis on the basis of a series of indicators (Table 1).

Table 1. Classification table of indicators

\begin{tabular}{|c|c|c|c|}
\hline Theme & Indicator & Value & Procedure / Field of complete registration of metadata \\
\hline \multirow{3}{*}{ Descriptives } & $\begin{array}{l}\text { Name and access to repo- } \\
\text { sitory }\end{array}$ & [Name and URL] & Record of name and URL \\
\hline & $\begin{array}{l}\text { Institution to which it } \\
\text { belongs }\end{array}$ & [University name] & Record of name and acronyms \\
\hline & Open access policy & {$[\mathrm{Yes} / \mathrm{No}]$} & $\begin{array}{l}\text { Navigation (section on repository) or direct search for } \\
\text { policy (by title) }\end{array}$ \\
\hline \multirow{3}{*}{$\begin{array}{l}\text { Timeline and volume } \\
\text { of educational resour- } \\
\text { ces (in educational or } \\
\text { academic commu- } \\
\text { nities) }\end{array}$} & $\begin{array}{l}\text { Total number of teaching } \\
\text { collections available }\end{array}$ & [Number] & $\begin{array}{l}\text { Navigation and record of collections/ subcommunities } \\
\text { included in teaching or academic community }\end{array}$ \\
\hline & $\begin{array}{l}\text { Total number of resources } \\
\text { in the community }\end{array}$ & [Number] See Figure 1 & $\begin{array}{l}\text { Number of resources (filtering by type or manually, } \\
\text { adding up totals for each type }\end{array}$ \\
\hline & $\begin{array}{l}\text { Publication date of first } \\
\text { educational resource }\end{array}$ & $\begin{array}{l}\text { [Year format] See } \\
\text { Figure } 2\end{array}$ & $\begin{array}{l}\text { Search and record/dc.date.accessioned o dc.date. } \\
\text { available }\end{array}$ \\
\hline \multirow{5}{*}{$\begin{array}{l}\text { Principal characte- } \\
\text { ristics of educa- } \\
\text { tional resources } \\
\text { (in educational or } \\
\text { academic commu- } \\
\text { nities }\end{array}$} & OER types & $\begin{array}{l}\text { [exercises, notes, etc.] } \\
\text { See Figure } 3\end{array}$ & $\begin{array}{l}\text { Search for types established within the collections/ } \\
\text { subcommunities/ dc.type }\end{array}$ \\
\hline & Metadata standard & $\begin{array}{l}\text { [Dublin Core, Marc21, } \\
\text { etc.] }\end{array}$ & Search in deposit policies/ checking metadata \\
\hline & $\begin{array}{l}\text { Terms used in metadata } \\
\text { type }\end{array}$ & $\begin{array}{l}\text { [lecture, learning } \\
\text { object, other, etc.] See } \\
\text { Figure } 4\end{array}$ & Search and record/ dc.type \\
\hline & User licences & $\begin{array}{l}{[C C \text { BY, CC BY-NC-ND, }} \\
\text { etc.] See Figure } 5\end{array}$ & Search and record/ dc.rights or dc.rights.acessRights \\
\hline & Formats & $\begin{array}{l}\text { [pdf, jpg, xml, etc.] See } \\
\text { Table } 6\end{array}$ & $\begin{array}{l}\text { Filter for format, check field format (in the item file) } \\
\text { or dc.format.mimetype }\end{array}$ \\
\hline
\end{tabular}

The data collection was conducted manually, accessing the teaching community of each repository and inspecting the subcommunities and collections contained within it. Firstly, available filter options were examined, to check whether the information displayed in them allowed the recording of data such as the date and type of resources. Then, a number of searches were carried out in each collection and a random selection of results to review the complete record of metadata and record relevant data for the purpose of the investigation. The procedure was completed by consulting the documentation of each repository (mission, deposit policies, etc.). The results obtained allowed the clarification of the two remaining research objectives (O4 and 05 ), described below.

First, in order to identify the principal characteristics of the educational resources included in the teaching communities of IRs in Rebiun (O4), existing collections within them (type, volume and timeline) and the objects contained within them (type, user licences, metadata and formats) were analysed. It was necessary to establish some parameters to homogenize the data collection; for example, a series of equivalences to typify the resources (Table 2).

Secondly, with a view to discover the stage of development of teaching collections and the resources deposited in them (O5), a classification of the repositories according to their various stages of development has been proposed. In turn, this classification was determined on the basis of two criteria (see Table 3):

- The purpose of the resources contained within them: if they are educational resources created exclusively for the purpose of teaching and learning, or resources with a different purpose (more closely related to the fields of research, academia, student innovation or student work).

- The level of access and re-usability of the OER: if the educational resources created exclusively for the purposes of teaching and learning have any other type of open Creative Commons (CC) licence, or any other licence that permits its re-use (CC BY, BY-SA, BY-NC o BY-NC-SA) 
Table 2. Standardised nomenclature for types of educational resources

\begin{tabular}{|c|c|}
\hline Original OER types & Equivalent concept \\
\hline Class notes and presentations & Notes \\
\hline Published articles in academic journals & Articles \\
\hline Documentary/ report & Audiovisuals \\
\hline Book section & Book chapters \\
\hline Lecture/class, lessons, introductory lessons & Classes \\
\hline Conferences and symposiums, symposiums, events, seminars & Conferences \\
\hline Conferences papers, communications, presentations, posters & Communication/presentation \\
\hline Didactic courses & Courses \\
\hline $\begin{array}{l}\text { Exercises and solutions, solutions to exercises, problems, online } \\
\text { exercises }\end{array}$ & Exercises and problems \\
\hline Midterm or final exams, with or without solutions & Exams \\
\hline Collections of images & Images \\
\hline Books & Books \\
\hline Student guides, study guides, teaching guides, guides, syllabuses & Teaching guides \\
\hline Guides, tutorials, teaching manuals, manuals & Guides and manuals \\
\hline Report, technical report, report, working papers & Technical reports \\
\hline Transcription of literary works & Readings \\
\hline End-of-course projects & End-of-course projects \\
\hline $\begin{array}{l}\text { Information sources and resources, academic material, didactic ma- } \\
\text { terial, teaching material, learning resources and teaching resources }\end{array}$ & Other \\
\hline Teaching portfolios & Teaching portfolios \\
\hline Practicum, practical cases & Placements \\
\hline Teaching innovation projects & Teaching innovation projects \\
\hline Simulations and interactive resources & Simulations and interactive resources \\
\hline Software. Applications for use in teaching & Software \\
\hline Doctoral theses & Doctoral theses \\
\hline $\begin{array}{l}\text { End-of-degree projects, end-of-course projects, masters theses. } \\
\text { Masters' projects }\end{array}$ & Final projects (TFEs: Trabajos final de estudios) \\
\hline Tasks carried out by students, used as course content & Student projects \\
\hline
\end{tabular}

Table 3. Types of resources deposited in teaching communities according to purpose and level of openness

\begin{tabular}{|l|l|l|}
\hline Resources & According to purpose and level of openness & According to type of resource \\
\hline Research resources & $\begin{array}{l}\text { Research environment, created by teaching staff / } \\
\text { researchers }\end{array}$ & $\begin{array}{l}\text { Articles, conferences, communication/presenta- } \\
\text { tions, technical reports, doctoral theses }\end{array}$ \\
\hline Academic material & Teaching environment, created by academic units & $\begin{array}{l}\text { Didactic guides, end-of-course projects, images, tea- } \\
\text { ching portfolios }\end{array}$ \\
\hline $\begin{array}{l}\text { Teaching innovation } \\
\text { material }\end{array}$ & $\begin{array}{l}\text { Teaching environment, created by academic staff } \\
\text { or teaching support units }\end{array}$ & $\begin{array}{l}\text { Articles, conferences, communications/presentations, } \\
\text { technical reports, teaching innovation projects }\end{array}$ \\
\hline Final projects & Learning environment, created by students & TFE, student projects \\
\hline OER & $\begin{array}{l}\text { Created by teaching staff solely for teaching and } \\
\text { learning and with open licence (any CC) }\end{array}$ & $\begin{array}{l}\text { Notes, audiovisuals, book chapters, class, courses, } \\
\text { exercises and problems, exams, images, books, } \\
\text { guides and manuals, readings, others, teaching } \\
\text { portfolios, placements, simulations and interactive } \\
\text { resources, software }\end{array}$ \\
\hline $\begin{array}{l}\text { REA, nivel alto de aper- } \\
\text { tura y reutilización }\end{array}$ & $\begin{array}{l}\text { Created by teaching staff solely for teaching and } \\
\text { learning and with a licence that permits its re-use } \\
\text { (CC BY, BY-SA or BY-NC-SA, CC BY-NC) }\end{array}$ \\
\hline
\end{tabular}

The generated datasets in the content analysis are found openly accessible in the UPCommons repository: http://hdl.handle.net/2117/327183

Finally, we will also signpost some limitations: on one hand, not all systems provided the necessary filters to perform calculations or identify data, and on the other hand, the metadata analysis performed on some records (although it aimed to cover the maximum possible) is not representative of the total. Nonetheless, the data collected has made it possible to clarify the current situation of IR teaching collections and lay the foundations for a future study that will more deeply examine aspects that prove to be relevant. 


\section{Results and analysis}

\subsection{OER in Spanish universities}

\subsubsection{Publication platforms and co-existence between them Internal platforms}

The data obtained in the survey shows that virtual campuses are the main educational content management tool used by Spanish universities. This occurs in precisely $88.6 \%$ of cases (47 institutions), among which $13.20 \%$ (7) state that this is the only platform used for this purpose. This is to be expected, since these are widely used services in universities, and often provide management applications for content or authorship (Gómez-Ortega, 2017).

In second place we find IRs (77.3\%, 41 institutions). OCW platforms are the third system of internal publication of educational resources, with only $32 \%$ (17 institutions).

The adoption of virtual campuses for the management of educational content raises some questions about their effectiveness. On one hand, these are platforms with access restricted to very specific user groups, with time limits, because educational resources are renewed (or not renewed) subject to the teacher's discretion, according to the academic year or module changes. Therefore, there is a lack of permanency and little control of resources (Bueno-De-la-Fuente; Hernández-Pérez, 2011) which also greatly limits the possibility of their discovery and re-use. Moreover, the level of interoperability between these platforms is still precarious and ad-hoc improvements are needed (Gómez-Ortega, 2017) in order to match services provided with those managed from external environments.

On the other hand, its complexity must be highlighted. It is no longer just a platform, but rather an ecosystem of services (Martí; Gisbert; Larraz, 2018), in which the management of educational resources requires its own processes with specialized systems and staff.

The other two institutional publication platforms for educational resources, IRs and OCW, present a similar situation. Although educational content has increased its presence considerably in IRs in recent years, it has been noted that they are still difficult to access and laborious to retrieve, for the reasons mentioned above (Romero-Peláez et al., 2019).

The OCW model, created in 2001, was one of the first widely used OER platforms. It emerged in Massachusetts Institute of Technology (MIT) in order to publish in open access all of the content created by its teaching staff to support the learning processes of the university. In 2008, Spain's participation in this initiative began, when the Universia Foundation set in motion the OpenCourseWare Universia program, to promote the implementation of OCW platforms in Spanish and Latin American universities, with the goal of sharing teaching materials structured by modules.

2010 was the year with the highest incorporation of Spanish universities into OCW

Universia (Abadal et al., 2013). In 2012, 46 universities in Spain were affiliated, with 29 OCWs in operation (Tovar, 2013) and in $2013,38 \%$ of universities affirmed that they used OCW as a system for storage and dissemination of educational resources (Fernández-Pampillón-Cesteros; Domínguez-Romero; De-Armas-Ranero, 2013).

Nonetheless, despite the initial success of the initiative at the time, currently, the project URL is no longer operational. Examining OCW in Spanish universities today, we find that the majority $(82.4 \%, 14)$ are not up to date, they redirect to other university systems, or they are no longer operational; with the exception of 3 institutions (in operation at the time of data analysis): Universitat de Lleida (UdL), Universidad de Cantabria (UC) and Universitat Politècnica de Catalunya $(U P C)$, this last one is in the process of migration to a repository. Therefore, the decline of the $O C W$ initiative is clearly seen, considering the timeline of events and the evidence displayed.

With regard to the overlap between institutional platforms, there is a greater convergence between virtual campuses and IRs, both present in 29 institutions (53\% of the total). In second place are those institutions that use IRs and OCW in conjunction $(28.3 \%, 15$ in total). Lastly, we find universities that combine the use of all three platforms: virtual campuses, IRs and $\operatorname{OCW}(26.4 \%, 14)$. Thus, 43 institutions $(79.4 \%)$ publish educational resources simultaneously in open (IRs and/ or OCW) and closed (virtual campuses) platforms.

\section{External systems}

The majority of institutions $(80 \%, 42)$ use some or various external channels (YouTube, SlideShare, Prezi, Issu, etc.) for the publication of and access to educational content. The 11 remaining institutions left their responses blank.

Regarding services external to the university, the use of YouTube stands out (in 37 institutions, 69.8\%), possibly motivated by the rise of multimedia content in education. In any case, the use of YouTube is not exclusive, as it coexists with proprietary systems such as virtual campuses, in 31 out of 37 institutions or, with IR and/or OCW, in 33 institutions. Next in line we find SlideShare (39.6\%, 21 institutions).

There was no single case identified in which the universities opted solely for the use of externally operated platforms, in 
order to manage their educational resources. Likely, this is due to the desire to leverage services developed outside the university, with the possibility of adding value to educational content, offering services that the institution itself could not provide, or responding to strategies that address the visibility and impact of its educational offerings.
Most institutions use one or more external channels (YouTube, SlideShare, Prezi, Issu, etc.) for the publication and access to educational content

However, we must stress the difficulty of identifying these systems, external to the institution, that are used for the management of educational resources. In this respect, the institutions that did not respond to this question may reveal the complex nature of locating other means used by teachers to produce and disseminate educational content. In many cases, we could be talking about documents that do not follow the production and publication channels established by the universities or documents that are available in very diverse formats and with a broad range of editing and access services.

Despite the services offered by these platforms, there are some aspects to consider regarding their use. Firstly, the licences which must be accepted for their use may be abusive in terms of the transfer of copyright. Teaching staff may be handing over the use of their teaching material unconsciously, thereby losing control of the content. However, the sustainability of these systems needs to be taken into account. There is a risk that closing a specific service may lead to the disappearance of the content that it hosts, making it very difficult to recover. Finally, these platforms are accustomed to using their own file formats, and therefore publication across other channels can prove difficult.

\section{MOOC platforms}

Data from the survey also showed the presence of OER in MOOC (massive open online courses) platforms or in massive and open online courses. The first MOOC, created in 2008 by George Siemens and Stephen Downes, bore the name Connectivism and connective knowledge (CCK08) and was based on the theory of connectivism which involves the creation of knowledge across nodes. From this, a number of MOOC online platforms were developed, such as Udacity, Coursera and $e d X$ (based in the US), FuturLearn (in the UK), MiríadaX (Ibero-American in scope), etc. Moreover, the original concept of MOOC has evolved and produced different variants: XMOOC (virtual learning centred on video viewing); SPOC (non-massive in scope and with closed content), MOOR (massive open online research) or DOCCIA (distributed open collaborative course).

The responses received show the pre-eminence of the MOOCs MiríadaX portal (in 30.1\%, 16 institutions), the first and largest platform in Spanish, launched in 2012 by Santander Bank and Universia Spain. The next significant MOOC platforms used in Spanish universities are Coursera $(7.5 \%, 4)$ and $e d X(3.7 \%, 3)$. Incidentally, it should be noted that the survey data corresponds, in part, to the current total of Spanish institutions registered in these MOOC platforms (with the exception of the 3 from edX), since they feature 36 in MiríadaX, and 2 in Coursera. It is likely that changes have occurred in the elapsed timeframe.

The emergence and rapid rise of MOOCs and their educational model, without formal requirements (no enrolment) or limits on participation (free and online open access) has caused some universities to make a decisive move towards them, as a strategy of institutional innovation (García-Peñalvo; Fidalgo-Blanco; Sein-Echaluce, 2017). It is important to point out that universities can create OER with the purpose of incorporating them into their MOOC offering (Santos-Hermosa, 2018) and that, in turn, OER generated in MOOC platforms can be integrated into academic courses.

\subsubsection{The impact of policies}

Broadly speaking, the survey data shows that $64.2 \%$ (34) of Spanish universities (Rebiun, 2019) have open access policies. These figures do not deviate from those registered in the ROAR directory Registry of Open Access Repository Mandates and Policies (Roarmap) which accounts for 36 universities and 3 research centres with this type of policy: https://roarmap.eprints.org

Over recent years, open access policies have been progressively on the rise. While in 2008 , only $9.4 \%$ of universities (7) had an open access mandate and $28 \%$ (21) did not record carrying out any action to promote one (Melero et al., 2009), by 2017, 33 institutions had developed a relevant policy (Barrueco et al., 2017).

\section{Specific policies and promotional strategies}

Although $91.1 \%$ (31) of institutions with a public open access policy publish their educational resources on institutional open platforms (whether IR, local or OCW), when we delve deeper into the nature of these policies, we see that only $46.1 \%$ of institutions (16), include any specific recommendations for the publication of OER. Hence, less than half of current policies expressly promote this practice.

The minor role of educational resources in such policies can be understood by analysing their temporal context. The majority of policies were created between 2008 and 2012 (Casal-Reyes et al., 2013), a period in which there was more interest in publishing resources for research rather than educational resources, promoted by Act 14/2011, of $1^{\text {st }}$ June, on Science, Technology and Innovation (Ley 14/2011, de 1 de junio, de la Ciencia, la Tecnología y la Innovación) (España, 
2011a) and Royal decree 99/2011, of $28^{\text {th }}$ January (Real decreto 99/2011, de 28 de enero) which regulate the official teaching of doctorates (España, 2011b; Casal-Reyes et al., 2013; Abadal et al., 2013). Interest in OER came later, after the Paris Declaration (Unesco, 2012), in which their creation, sharing and use is promoted.

In any event, the data shows that $8.8 \%$ (3) of institutions with an open access policy have (or are in process of developing) another specific OER policy (notably the universities of Murcia, the Balearic Islands and Lleida) and that 17.6\% (6) also have (or are considering the implementation of) a promotion policy for this type of resource (Table 4).

Table 4. OER promotion strategies

\begin{tabular}{|c|c|c|}
\hline Stage & Universities with an OA policy & Universities without an OA policy \\
\hline \multirow{3}{*}{$\begin{array}{l}\text { Have an online tea- } \\
\text { ching plan to promote } \\
\text { OER }\end{array}$} & $\begin{array}{l}\text { The institutional strategic plan establishes } \\
\text { strategies and policies for its dissemination }\end{array}$ & $\begin{array}{l}\text { There is a requirement for teaching materials that } \\
\text { receive grants for editing in the Valencian language to } \\
\text { be deposited in the institutional repository }\end{array}$ \\
\hline & $\begin{array}{l}\text { The Innovation Department of the university } \\
\text { develops plans with respect to fulfilling the } \\
\text { strategic objectives }\end{array}$ & $\begin{array}{l}\text { The Unit for Educational Technology and Teaching Inno- } \\
\text { vation (UTEID) which coordinates the library is respon- } \\
\text { sible for rolling out the university policy in relation to } \\
\text { digital education, including support for teaching staff } \\
\text { to publish MOOCs and SPOCs }\end{array}$ \\
\hline & $\begin{array}{l}\text { There is an online teaching plan that promo- } \\
\text { tes OER }\end{array}$ & $\begin{array}{l}\text { The current Teaching Innovation Plan includes the re- } \\
\text { quirement for the open publishing of learning objects }\end{array}$ \\
\hline \multirow{3}{*}{ In progress } & $\begin{array}{l}\text { A plan to promote the open publishing of } \\
\text { learning resources is being developed }\end{array}$ & $\begin{array}{l}\text { The creation of an open access policy for the univer- } \\
\text { sity is in progress, from which a policy for educational } \\
\text { resources will be derived }\end{array}$ \\
\hline & $\begin{array}{l}\text { The viability of a repository containing the } \\
\text { entirety of educational resources generated } \\
\text { by the university is being assessed }\end{array}$ & $\begin{array}{l}\text { The open access policy and OER policy are both in the } \\
\text { stages of development and approval }\end{array}$ \\
\hline & Possible strategies are being investigated & $\begin{array}{l}\text { We are working on a portal for educational objects on } \\
\text { video }\end{array}$ \\
\hline \multirow{3}{*}{ Calls and grants } & & $\begin{array}{l}\text { Calls for a selection process for the support program } \\
\text { for the development and publication of free teaching } \\
\text { materials }\end{array}$ \\
\hline & & $\begin{array}{l}\text { Annual grants for the publication of MOOC (which im- } \\
\text { plies the generation of open educational materials and } \\
\text { their depositing in the repository) }\end{array}$ \\
\hline & & $\begin{array}{l}\text { Calls for a selection process for the support program } \\
\text { for the development and publication of free teaching } \\
\text { materials }\end{array}$ \\
\hline
\end{tabular}

With regard to universities that have no open access policy $(35.8 \%, 19)$, contrary to what one might expect, it has been observed that $78.9 \%$ (15) also publish educational resources on institutional platforms. This percentage is lower than in the universities that have open access policies. Moreover, in these universities with no open access policy, it has been identified that there are more cases working towards an OER promotional strategy (Table 4).

In concrete terms, $47.3 \%$ (9) have specific promotional units (3), are in the process of development (3), or even benefit from institutional grants (6). Some promotional activities are being conducted in the area of teaching innovation in Universidad Internacional de Andalucía (UNIA) and the Educational Technology and Teaching Innovation Unit (UTEID) in Universidad Carlos III de Madrid (UC3M). Of particular note, are the calls for the creation and publication of OER promoted by Universidad Politécnica de Valencia (UPV), Universitat Jaume I (UJI) and Universidad de La Laguna (ULL).

Therefore, the data shows that, while the specific policies of educational resources seem to be linked to universities that previously had an open access policy, the promotional strategy approach is not directly related to the policies but rather to departments and concrete actions at an institutional level. In the first case, it seems logical that open access policies could provide a foundation for other more specific policies, as well as helping to foster a favourable institutional context; as the Vice-Rectorate for Globalization and Cooperation at Universitat Oberta de Catalunya (UOC).. In the second case, the existence of Teaching Innovation Units, together with other strategies, such as author incentives (analysed below), encourage the creation of OER not only for publication in repositories and OCW, but also for MOOCs and other educational platforms. For example, the Comprehensive teaching plan (Plan propio integral de docencia) in UMA (Universidad de Málaga) relates to the promotion of teaching publications and open virtual courses, such as OCW, MOOCS and SPOCs. (Universidad de Málaga, 2019).

\subsubsection{Incentives for authors}

The offer of incentives for teaching staff for the creation of OER is rare; it only occurs in $29.7 \%$ of the total (Rebiun, 2019). On deeper analysis (Table 5), we observe that these incentives are economic (9 universities) or academic (4) in nature. 
Table 5. Incentives for OER development

\begin{tabular}{|l|l|c|}
\hline Type & Incentive & Number of universities \\
\hline \multirow{3}{*}{ Economic } & Financial supplement for OER creation & 3 \\
\cline { 2 - 3 } & Competitive call for grants for OER creation & 3 \\
\cline { 2 - 3 } & Recognition in teaching hours & 3 \\
\hline \multirow{2}{*}{ Academic } & Merit in teaching appraisal & 2 \\
\cline { 2 - 3 } & Diploma or certificate & 2 \\
\hline
\end{tabular}

In Spain, incentives first came from Agencia Nacional de Evaluación de la Calidad y Acreditación (Aneca) (National Agency for Quality Assessment and Accreditation), which, within the framework of the Support program for the evaluation of teaching activity of university teaching staff (Docentia), proposed, in its evaluation model, a section dedicated to teaching materials and resources (Aneca, 2007).

On the basis of this model, some universities have introduced the publication of open access materials as evaluation criteria for teaching or in return for financial remuneration. By way of example, the teaching evaluation manual of Universitat de València (UV) includes the development of OCW materials or materials with CC licence (Universitat de València, 2019) as one of its criteria for merit. Furthermore, the Manual d'avaluació docent del professorat (teaching evaluation manual for lecturers) in $U d L$ highlights the development of materials in the OCW belonging to the university, in Section 3.2.2. (Universitat de Lleida, 2016).

Despite the initiatives mentioned, it is important to reiterate the exceptional nature of the incentives granted, and that they carry little weight, in relation to the total merits that can be awarded. Although some studies (López-Martín, 2018) endorse the value of incentives to promote educational innovation and teaching excellence, the open publication of educational materials are not usually included as a requirement. This situation had already been detected in the context of $O C W$, where the lack of incentives had resulted in a social barrier with a direct effect on the success of open education initiatives (Tovar, 2013). Moreover, it has also been found that in $18.4 \%$ of cases (Casal-Reyes et al., 2013), Spanish universities in their consideration of IR publications, when promoting teaching and research staff, refer more to research resources, as required by the accreditations of evaluation bodies.

Beyond credit and incentives, some of the motivational factors for teaching staff to create and share OER are altruistic in nature; in other words, out of a conviction about or support for open-access knowledge. Other reasons identified in the literature (Banzato, 2012; Belikov; Bodily, 2016), that support an open education practice are,

- to assure the quality of resources;

- to make adequate information available about user licences; and

- to provide clarity on the difference between digital resources and OER.

If we examine the relationship between incentives and open access policies, the survey data shows that only $35 \%$ of universities with an open access policy also offer incentives for the creation of material. To be specific, out of the 34 universities that have an open access policy, only 5 have considered some type of incentive for authors who publish OER, implying that $9.43 \%$, and, out of the 19 remaining without a policy, only 6 report having any initiative around incentives.

Thus, this suggests that the presence or absence of an open access policy does not bear a great influence on the decision to offer incentives to publish OER. In turn, as previously mentioned, the promotional strategies seem to have a more significant relationship to incentives; given that $50 \%$ (11) of universities who report having (or having planned) promotional strategies or plans include some kind of incentive.

\subsection{OER in institutional repositories and $O C W$ platforms}

The content analysis carried out demonstrates some of the principal characteristics of the 45 IRs with teaching communities, with regards to their collections and the resources deposited within them. In concrete terms, we will set out the total volume of educational resources, the timeline of the appearance of teaching collections, the range of resource types, as well as their metadata, formats and user licences. All of these aspects are presented in relation to the number of IRs that consider them. Therefore, considering that a single repository includes more than one type of resource, metadata, licence or format, the tables and figures display the distribution of the total amount of resources, metadata, licences and formats in the 45 IRs.

The 45 IRs analysed make up $58.4 \%$ of the current total in Rebiun. This fact signifies an increase in the presence of educational resources in this type of repository, given that in 2007 they were only recorded in $39 \%$ of cases (Rebiun, 2007) and, in 2012, accounted for between 46.1\% (12 out of 26) (Fernández-Pampillón-Cesteros; Domínguez-Romero; De-Armas-Ranero 2013) and 50\% (Casal-Reyes et al., 2013) of the total. 
If we focus on other storage and retrieval systems for educational resources, such as $O C W$, the trend is the opposite: the presence of educational resources has decreased, compared to the past. In 2012, 38\% of universities (10 out of 27) stated that they used OCW (Fernández-Pampillón-Cesteros; Domínguez-Romero; De-Armas-Ranero, 2013) compared to $33.9 \%$ (18 out of 53 ) in 2018. This reinforces the idea of the decline of $O C W$, as previously mentioned.

\subsubsection{Volume}

It was calculated that there are around 240,160 educational resources, deposited in approximately 80 specific collections within teaching communities. In any case, it is clear that the total count of resources corresponds to 36 repositories, because in the 9 remaining cases (20\%), it was not possible to count the resources included. The difficulty lies in the fact that the collections appear in the form of lists without the numerical details of items; there is no limiter or filter according to the type of resource, or there are collections with restricted access.

The total volume of educational resources presently identified suggests an exponential rise when compared to earlier results: 1,725 items registered in 2007 (Rebiun, 2007) and 5,889 in 2008 (Melero et al., 2009).

With regards to the concentration of resources (Figure 1), it can be seen that $44.4 \%$ of teaching communities (20 repositories) house less than 1,000 educational resources, $24.4 \%$ (11) have between 1,000 and 10,000 and only $11.11 \%$ (5) contain more than 10,000 .

The low volume of resources in the majority of repositories is not a new insight, given that the sparse presence of teaching materials in IRs had already been identified (Gómez-Castaño et al., 2015). It has even been demonstrated (Ochoa, 2011) that the publication rate per contributor is smaller in scale ( 2 resources on average) in IRs than in educational repositories (10 resources) or other learning management systems (40 resources).

Regarding cases with a greater volume of resources, the repositories that stand out are the Depósito digital de documentos (Digital repository of documents) from Universitat Autònoma de Barcelona (UAB) and Zaguán from Universidad de Zaragoza (Unizar), with 60,652 and 25,921 teaching guides respectively. This is due to the fact that these universities are carrying out open publication projects of their teaching guides. UPCommons (UPC) also provides 30,272 exams and 270 courses. Riunet (UPV) has a large collection of audiovisual materials from Polimedia, due to its online teaching plan and RUA from Universidad de Alicante (UA) has carried out an average of 899 deposits of educational resources over the last 10 years.

\subsubsection{Timeline}

The first IR can be traced back to 2005, and corresponds to the $D D D$ repository from $U A B$ (Figure 2). It is important to note that the repository from Universitat de Barcelona (UB) was created in 2006 exclusively as an educational portal and it was later when it evolved into an IR and began to incorporate research resources. The UA repository was also one of the first with a teaching community. In any event, it is important to note that these dates refer exclusively to IRs, as the first educational repository registered is $M D X$, dating from 2001 (Melero et al., 2009).

It has been noted that the period of greatest increase in the creation of collections of educational resources was between 2008 and 2011 (Figure 2), with two peaks (2008 and, most notably, 2010) in which the greatest number of repositories with teaching communities were recorded. These dates fully coincide with the situation of IRs at that time, since the creation of

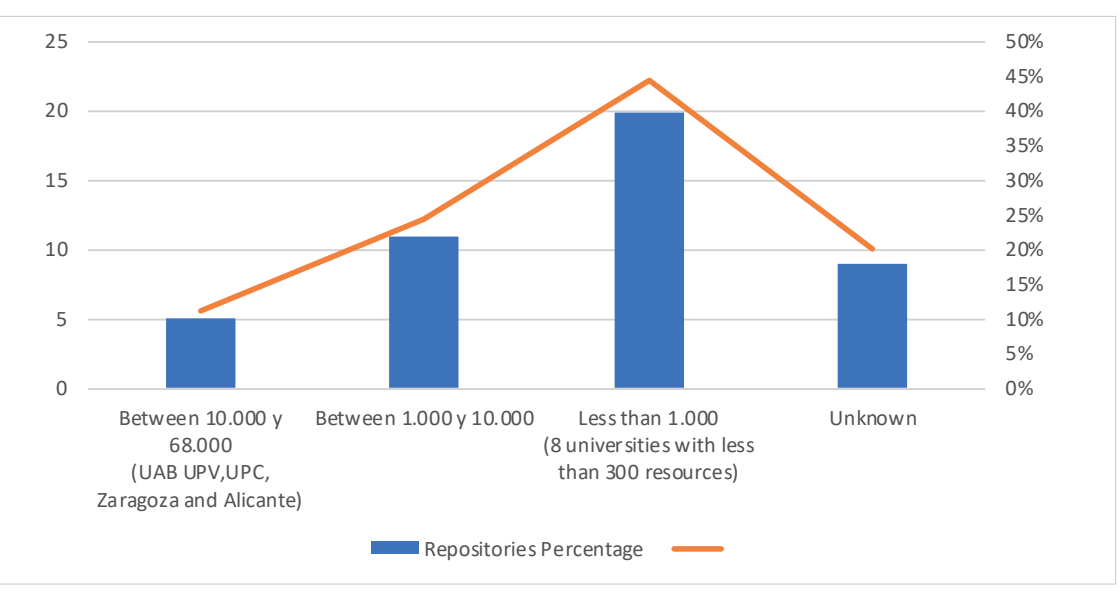

Figure 1. Volume of educational resources in repositories

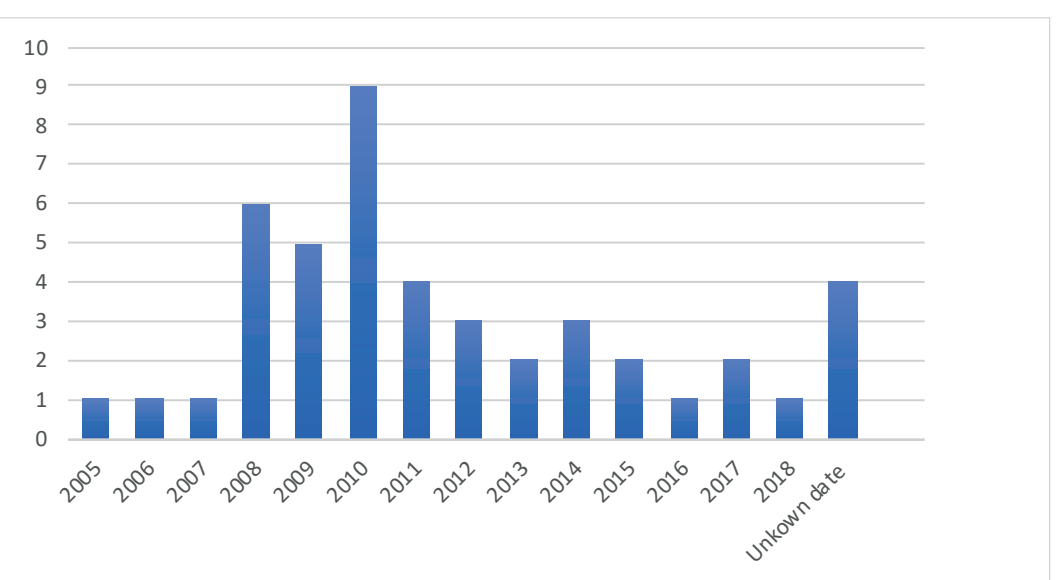

Figure 2. Evolution of the creation of teaching collections in IRs 


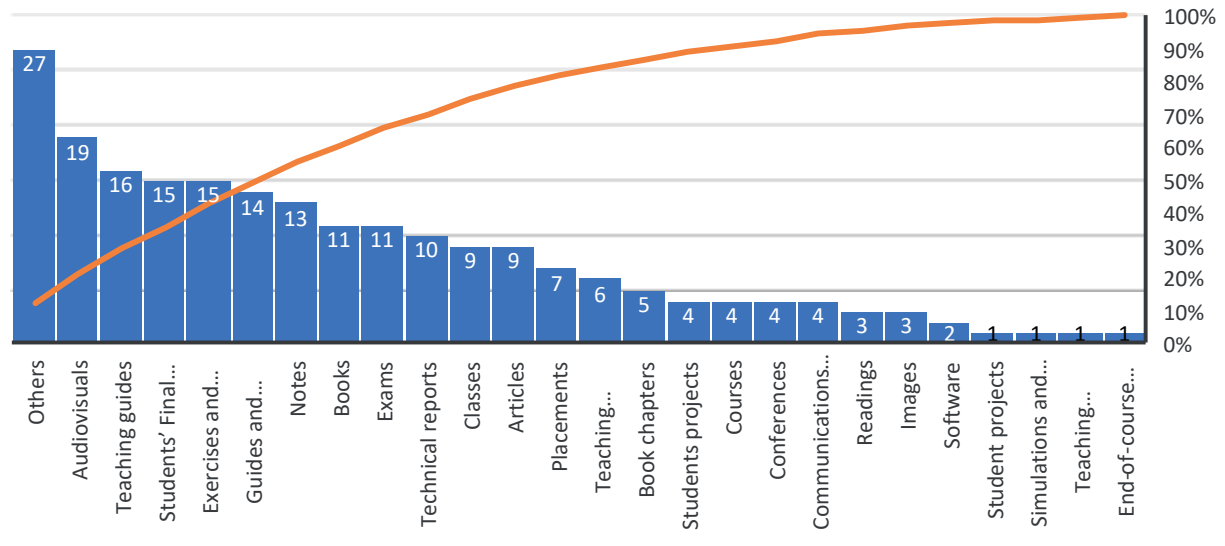

Figure 3. Number of repositories according to OER types

IRs began in the year 2000 and grew constantly from 2006 (Bueno-de-la-Fuente, 2010; Casal-Reyes et al., 2013). Then, consequently, teaching collections appeared in 2005-2006 and intensified until 2011.

Meanwhile, it has not been possible to identify the date of creation (or date of the first item sent) of the teaching collections in four repositories because it was not possible to filter or order by sending date or, because there was an inconsistency between sending date and real publication date of the resource. Nor has it been viable to differentiate by metadata according to date of entry in the repository (dc.date.accessioned, dc.date.available).

\subsubsection{Type}

The type of documents of Spanish IRs is heterogeneous. In the methodology we mentioned the nomenclature used to classify educational resources (Table 2). Below, this is supplemented with the number of repositories that include each type (Figure 3).

The type 'others' is very prevalent, present in $60 \%$ (27) of the universities analysed.

This finding is not surprising because, as we will see, there is not a generalised use of standards of educational metadata and, together with the lack of contextualization offered in repositories regarding the use of resources in subjects or courses, its typification is often complex.

The number of resources of a practical nature, such as exercises and problems, didactic guides and manuals or exams stand out significantly. In addition to this, we find class notes, books, classes or book chapters, more likely in contexts oriented towards theoretical content.

Audiovisual content is gaining more and more prominence in universities, incorporating them into their collections as educational resources. These resources are usually video recordings of classes, conferences or symposiums and, more recently, they have also been used to present course content. For example, the Polimedia project in UPV is available in its IR and constitutes a benchmark in its field (Turró et al., 2016).

Final projects (TFEs) also have an important presence in the collections of educational content of universities, even though international projects directed towards scientific production, such as OpenAire, regard them as the first research project and some universities, such as UPC, frame them in this context.

On the other hand, the presence of documents more typical of scientific communication (journal articles, technical reports, teaching innovation projects or papers) is directly related to the fact that institutions increasingly incorporate, in their teaching collections, initiatives and publications related to teaching innovation in their university.

The data analysis also sheds light on the limited presence of contents likely to have a high level of updates (such as teaching portfolios and software) or interactivity. The reason could be that IR and OCW are often designed with the publication of final versions of documents in mind, and ill-prepared for the management of derivatives or interaction with other systems.

Up until now, there has been little empirical evidence exhibiting the type of educational resources available in Spanish IRs because, with the exception of OCW courses, the previous literature usually refers, in general, to digital documents derived from academic work in universities, without specifying its type (Fernández-Pampillón-Cesteros; Domínguez-Romero; De-Armas-Ranero, 2013; Casal-Reyes et al., 2013). Moreover, although Bueno-De-la-Fuente (2010) considers which materials are most used in higher education, she does not provide additional information about each type. 


\subsubsection{Metadata}

93.3\% of IRs (42) use Dublin Core (DC) as a metadata schema, with and without qualifiers, to define learning objects. If we add the fact that one of the remaining repositories, the e-prints from Universidad Complutense de Madrid (UCM), has a standard of personalized metadata for each type from the basic scheme of DC, the percentage rises to $95.5 \%$ (43).

The $D D D$ repository, from $U A B$, describes the learning objects using the Marc21 metadata schema, but it maps the data in other formats: MARCXML, DC and Europeana Data Model (EDM). Lastly, the Summa repository from Universidad Pontificia de Salamanca (UPSA), uses a free metadata schema of the Pandora program.

The metadata schema employed is closely linked to the software used by each institution. For this reason, since $93.3 \%$ of the institutions (42) use DSpace to develop their IRs, DC is the default metadata schema. This accords with the findings of earlier studies (Melero et al., 2009) which, furthermore, also warn about the weakness of pedagogical metadata (Rodés-Paragarino; Gewerc-Barujel; Llamas-Nistal, 2015) and question the adequacy of using this schema for every type of resource, such as, for example, educational resources.

The 3 remaining institutions use different software: for example, ePrints, in Universidad Complutense, although the metadata models are also DC; CDS-Invenio, in UAB, and finally, Pandora, in UPSA.

Therefore, in general, universities do not use the most appropriate schema to describe learning objects, such as Learning Object Metadata (LOM) or local variants, such as LOM-ES for Spain. Only some IRs, such as Riunet (UPV) or the Bucle (Consortium of University Libraries from Castile and Leon) repositories, use their own metadata adapting the DC schema to LOM (Morales-Morgado; Campos-Ortuño; Ferreras-Fernández, 2019). The result is DC.LOM specific for educational resources, for example: dc.lom.learningResourceType, dc.lom.interactivityLevel, dc.lom.intendedEndUserRole, etc. https://poliscience.blogs.upv.es/2020/02/13/los-objetos-de-aprendizaje-de-riunet-en-merlot/?lang=CA

Concerning the population analysed, it was found that $68.9 \%$ (31) of IRs use a double-layer metadata system: the semantic structure OpenAire - Driver (info:eu-repo/) and the type term (Type DC), whether in English, or in Spanish or Catalan translations (Figure 4, top). In addition, it has been possible to identify the volume of repositories that use each metadata system (comparative in Figure 4).

\subsubsection{Licences}

The use of open CC licences is widespread in Spanish IRs, as previously discovered (Casal-Reyes et al., 2013). Nonetheless, despite the variety and prominence of open licences (Figure 5), it is also possible to find institutions that have teaching resources with all rights reserved or restricted access (for the most part, these are collections of exams).

The type of licence most frequently used for educational resources in IRs is BY-NC-ND, occurring in $82.2 \%$ of cases (37). This is the most restrictive licence, which allows the downloading and sharing of resources only when credit is given to the author but does not allow modification or use for commercial purposes. This suggests that independent of the policy, the authors (and institutions) have an interest in allowing online access to content, but are reluctant for their resources, produced for educational purposes, to be commercially exploited and in other cases, it is due to a lack of knowledge around in-

\section{Metadata Type Dublin Core}

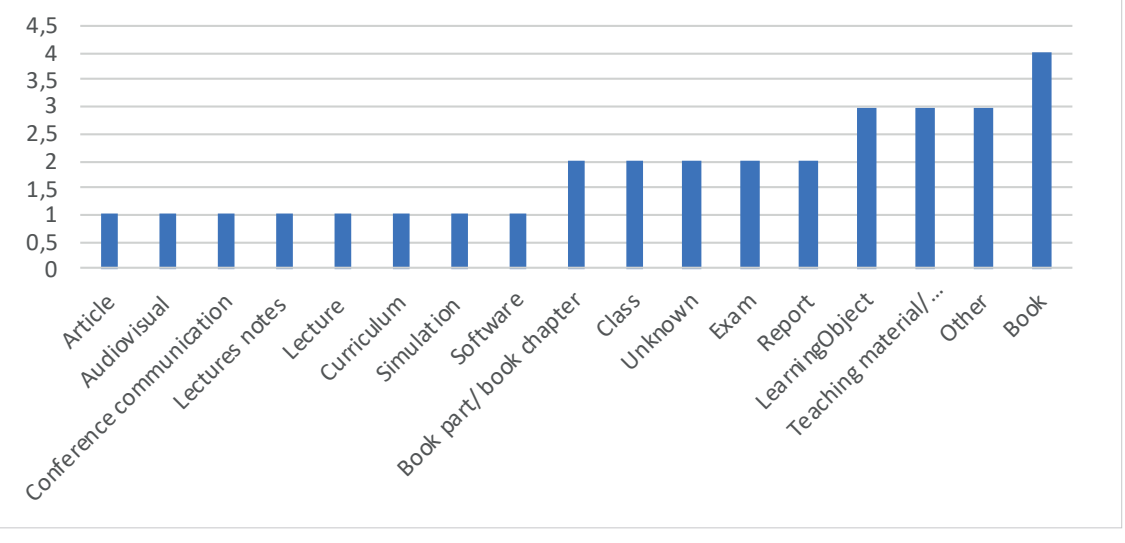

Metada OpenAire Guidelines

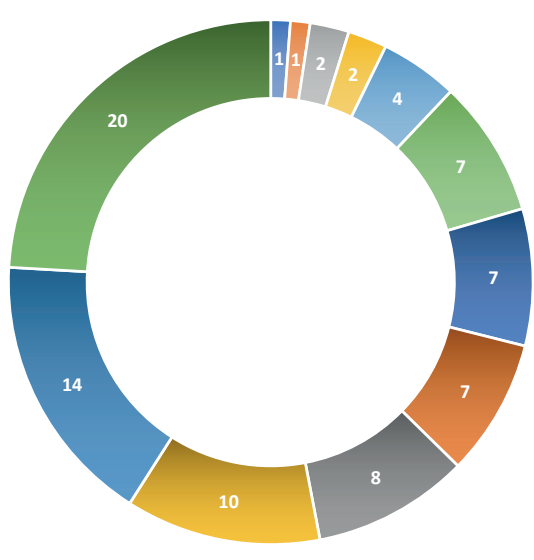

m info:eu-repo/semantics/annotation

- info:eu-repo/semantics/studentThesis

- info:eu-repo/semantics/doctoralthesis

info:eu-repo/semantics/LearningObject

info:eu-repo/semantics/bookPart

- info:eu-repo/semantics/article

- info:eu-repo/semantics/conferenceObject

- info:eu-repo/semantics/report

- info:eu-repo/semantics/lecture

m info:eu-repo/semantics/workingPaper

n info:eu-repo/semantics/book

n info:eu-repo/semantics/other

Figure 4. Volume of repositories by OER metadata types 
tellectual property legislation (McGreal; Miao; Mishra, 2016).

By comparison, the second most common licence is the BY-NC-SA which does not allow commercial use either but does permit the creation of derivatives (as long as they have the same licence as the original resource). This variable facilitates the adaption and remixing of educational resources, and, therefore, has a greater degree of openness allowing its re-use.

Focusing on re-use, the data collected shows that 17 IRs (37.7\%) have educational resources deposited under one of the four CC licences (BY, BY-SA, BY-NC or BY-NC-SA) which permits re-use (Figure

6). However, certain discrepancies can be identified with regard to the previous literature. While the study carried out by Barrueco et al. (2014) recognised that 78\% included CC licences for reuse of deposited items (without specifying which items), the data collected in the Rebiun survey (2019) records that only $43.3 \%$ (23 IRs) use CC licences that allow remixing (BY, BY-SA, BY-NC or BY-NC-SA).

The discrepancy identified between the university responses in the survey and the data registered in the present study (6 IRs), is probably due to confusion between the availability of licences that the IRs offer to authors, and the licences with which educational resources are published within the institutions. It is also worth mentioning that the analysis conducted does not cover the entirety of educational resources and their licences, due to the impossibility of filtering by licence and of conducting a manual review item by item.

The experts (Green, 2017; Butcher; Kanwar; Uvalic-Trumbic, 2015) consider that not all CC licences are adequate for creating OER, because although all of them allow a copy of a resource to be made (fundamental permission for opening), some restrict adaptations and do not allow compliance with the rest of the necessary 5 Rs (reuse, revise, remix, redistribute, retain), for a resource to be truly considered OER (Wiley, 2019).

From this perspective, educational resources with BY-NC-ND and BY-ND licences (recorded in $80 \%$ of the total IRs, 36) would not be considered OER (Figure 6); since the first (BY-NC-ND) only allows one of the 5 Rs (Retain: make a copy of the resource), and the second (BY-ND), would comply with 2 other Rs: to share (Redistribute) and reuse them as they are without any modification (Reuse).

With regard to the rest of the CC licences (BY, BY-SA, BY-NC-SA, BY-NC), recorded in $42.2 \%$ (19 IRs) of cases, they do permit reuse, provided that credit is given to authors and that certain requirements (for example, the requirement that derivative resources use the same licence) and restrictions (such as prohibiting "commercial" use) are met. In this sense, these other licences show different levels of openness and consideration of the concept, with respect to the fulfilment of the Wiley's 5Rs (2019). In specific terms, the four licences allow the adaption of resources (revise) and allow them to be combined to make a derivative work (remix) and the difference is the permission for commercialization or lack thereof (BY/BY-SA and BY-NC-SA/ BY-NC, respectively).

\subsubsection{Formats}

The types of file format are very diverse, even for the same resource type, as shown in Table 6 . The most frequently used formats are: .pdf, common for text in all IRs; .mp4, for audiovisual resources and .mp3, for sound files; .jpeg and .png for images; .ppt or .pptx for presentations; .html for web and .zip and .rar, for compressed files.

The file format is a crucial aspect for the visualization, interoperability, reuse and preservation of a resource, but even more crucial is the use of open standards, in the case of resources to be reused in educational activities. In accordance with the IANA (Internet Assigned Numbers Authority) format registry, in the ab-

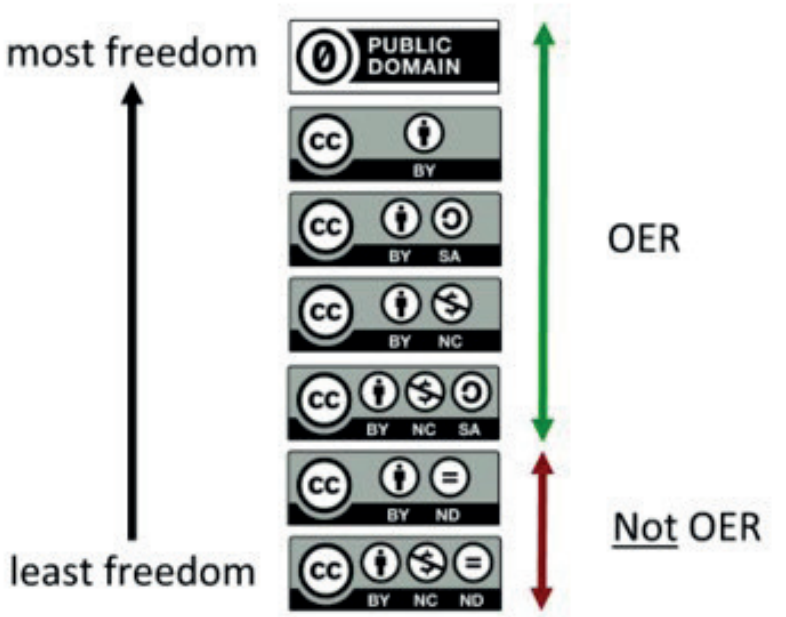

Figure 6. Creative Commons and OER licences (Green, 2017) 
sence of the openformats.org initiative (currently not available) and depending on current versions and standardizations, some of the formats identified in the IRs can be considered open, such as in the cases of text / web (.odt, .html), image (.png) and compression (.zip). By contrast, more shortcomings can be noted with regard to technical openness in the formats for audiovisual resources, audios and presentations, where proprietary programs are used. According to the analysis carried out, this would be the case for $55 \%$ of formats in the Spanish IRs. The great variety of formats, as well as the use of standardised files and files for preservation purposes, coincides with the findings of other studies (Bueno-De-la-Fuente, 2010; Santos-Hermosa; Ferran-Ferrer; Abadal, 2017).

https://www.iana.org/assignments/media-types/media-types.xhtml

We should highlight some considerations regarding the dominant format of IRs. Although .pdf was standardised as an open access version (ISO 32000-1), some of its characteristics continue be-

ing proprietary, so that access to editing tools is limited for .pdf files in comparison to other file formats such as .html, which provide access to the source file.

In this vein, it is important to bear in mind that even if a resource has been licensed for reuse, redistribution, revision and remixing, there are various technical factors that also affect its "openness", particularly in terms of revision and remixing. In other words, it is also necessary that authors or editors unlock their resources so that they can be adapted and allow more users to practise the 5 Rs. A number of authors (Hilton et al., 2010) developed the ALMS framework to provide a guide to the different technical options to consider, in order that open content may be revised or remixed. This guide states that the publication format should be significantly editable (like a web); it should not require great technical abilities of the user (easy to use software); it should be possible to do with tools that are freely available (OpenOffice or $R T F)$; and that access should be provided to the source file.

\subsection{Classification of repositories according to their stage of development}

Once the principal features of the OER and the collections to which they belong were analysed, then, we proceeded to classify the repositories according to their stage of development (Table 7). This proposal for classification, as previously explained, is based on the purpose and level of openness of educational resources deposited; in other words, depending on whether they have been created for educational purposes or otherwise, and the degree of reuse permitted by their user licences.

Table 7. Stages of development of repositories according to type of teaching resources

\begin{tabular}{|c|c|c|c|}
\hline \multirow{2}{*}{$\begin{array}{c}\text { Stages } \\
0\end{array}$} & \multirow{2}{*}{$\begin{array}{ll} & \text { Description } \\
\text { Repositories with teaching community } & \end{array}$} & \multicolumn{2}{|c|}{ Repositories } \\
\hline & & 45 & $100 \%$ \\
\hline 1 & Repositories with teaching communities not exclusively formed by TFEs & 42 & $93,0 \%$ \\
\hline 2 & $\begin{array}{l}\text { Repositories with teaching communities that have a mix of resources: those created specifically } \\
\text { for teaching and learning (OER and OER, high level of openness and reuse) and resources with } \\
\text { other purposes (TFEs, teaching innovation, academic, and research materials). } \\
\text { See Table } 8\end{array}$ & 36 & $80,0 \%$ \\
\hline 3 & $\begin{array}{l}\text { Repositories with teaching communities that only contain OER created exclusively for teaching } \\
\text { and learning and holding some type of open licence. }\end{array}$ & 6 & $13,0 \%$ \\
\hline 4 & $\begin{array}{l}\text { Repositories with teaching communities that only contain OER created exclusively for teaching } \\
\text { and learning and holding licences permitting their reuse. }\end{array}$ & 4 & $8,8 \%$ \\
\hline
\end{tabular}

Stage 0: Initial stage composed of all the repositories with a teaching community (100\%, all 45 that we have analysed). 
Stage 1: The first stage relates to IRs with teaching communities that are not exclusively composed of TFEs. This corresponds to $93 \%$ (42 IRs) because it excludes the 3 that, at present, have created teaching collections only to deposit TFEs.

Stage 2: This makes up the majority of IRs (80\%, 36 IRs), which contain a mix of resources in their teaching communities: resources with open licences, created specifically for teaching and learning, together with other resources with some "educational" function, but not created or intended exclusively for that purpose. The latter tend to be related to the teaching, academic or research environment (Table 8). With regard to the characteristics observed in these 36 IRs, the following should be highlighted:

- 19 teaching communities include materials related to the area of teaching and learning (including resources created with this purpose and also collections of student work or materials on teaching innovation).

- 15 contain research resources, along with other types of educational material. This situation contributes to a certain distortion and heterogeneity in teaching communities.

- 2 have teaching collections that include academic resources, more closely related to administrative or institutional matters rather than teaching.

- 1 has resources with open licences for reuse (specifically BY, BY-SA and BY-NC-SA), along with other more restrictive licences.

Moreover, it can be seen that $63.8 \%$ (23 out of 36 ) contain TFEs within teaching communities. This suggests that, although many universities identify TFEs as a type of teaching resource, it is not a generalised consideration given that others have created a separate and specific community for TFEs. One final distinctive aspect of this stage is that there are more IRs with open access policies (63.81\%, 21 repository-specific and 2 institutional) than without (36.1\% remaining, 13).

Table 8. Outline of OER type and other resources in the teaching collections of institutional repositories

\begin{tabular}{|c|c|c|}
\hline Type of resource in teaching collections & Type of mix (OER and others) & $\begin{array}{l}\text { Number of } \\
\text { repositories }\end{array}$ \\
\hline \multirow{3}{*}{$\begin{array}{l}\text { Resources related to the teaching field (OER, final pro- } \\
\text { jects and teaching innovation materials) developed by } \\
\text { teaching staff, students or teaching support units }\end{array}$} & OER + final projects (FPs) & 11 \\
\hline & OER + teaching innovation material & 6 \\
\hline & $\mathrm{OER}+\mathrm{FPs}+$ teaching innovation material & 2 \\
\hline \multicolumn{2}{|l|}{ Subtotal mix of resources in the area of teaching } & $19(52.7 \%)$ \\
\hline $\begin{array}{l}\text { Resources related to the academic field (OER and } \\
\text { academic material) developed by units or academics }\end{array}$ & OER + academic material & 2 \\
\hline \multicolumn{2}{|l|}{ Subtotal mix of resources in academic area } & $2(5.5 \%)$ \\
\hline \multirow{4}{*}{ Resources related to research field } & OER + Research & 4 \\
\hline & $\mathrm{OER}+$ Research + FPs & 6 \\
\hline & OER + Research + teaching innovation material & 3 \\
\hline & OER + Research + Academic material & 2 \\
\hline \multicolumn{2}{|l|}{ Subtotal mix of resources in research area } & $15(41.6 \%)$ \\
\hline \multicolumn{2}{|l|}{ Total mix } & 36 \\
\hline
\end{tabular}

Stage 3: Relates to a small proportion of IRs $(13.3 \%, 6)$ with teaching communities that only contain OER with an open licence and created by teaching staff exclusively for teaching and learning. In this case, the following has been observed:

- All cases have a separate community for TFEs.

- A third of cases have OCW integrated into the repository (UII and UNIA) and were created more recently (UNIA and URiV).

This data, although not representative, suggests that IRs containing resources from OCW or teaching communities at a later point have been able to consider other methods of depositing that are more favourable or suitable to OER.

Stage 4: Composed of only $8.8 \%$ of cases and corresponding to 4 teaching communities that contain OER created exclusively for teaching and learning, and that also have a licence allowing reuse, in this case CC BY (2), BY-SA (1) and BY-NC-SA. At this point, it should be noted that although initially 17 IRs had been identified with licences for reuse, only 4 fulfil an exclusively educational purpose within their teaching communities. 


\section{Conclusions}

This study concludes that, in general, educational resources in Spanish universities are of heterogeneous type and limited openness. They tend to be published in a duplicated manner in platforms that are not interconnected, and although the total volume has increased when compared with the past, there still exists the need for greater institutional promotion and incentives for authors.

The duplicates identified in the publication of educational content occur, mainly, between open (IRs and OCW) and closed (virtual campuses) platforms belonging to the institutions. In any event, this pattern is also replicated in the case of internal and external platforms (most notably, in the case of audiovisuals and MOOCs). Most likely this is due to the fact that these platforms are offering services that universities, at present, do not provide. Nonetheless, there is not an exclusive use of a particular platform; rather there is a "disorderly" coexistence between them.

Moreover, certain limitations regarding the management of educational resources have been noted, as well as the abandonment of $\mathrm{OCW}$ by Spanish institutions. Possible reasons for this could be poor maintenance of software and of the interoperability standards used, the emergence and impact of MOOC courses, and the mismatch of platforms due to the difficulties implied with the model for the publication of courses.

Furthermore, it is important to note that the creation of educational resources in Spanish universities relates more to teaching innovation and to the use of ICT in teaching than to open publishing. This explains the rare mention of these resources in open access policies.

With regard to policies, it is evident that their existence does not influence the decision to offer incentives for publishing OER. In fact, the incentives offered by universities for their teachers to develop educational resources are rare. The few cases we detected in our analysis were economic or academic in nature and mostly began with calls from Aneca (National Agency for Quality Assessment and Accreditation). As mentioned throughout this paper, the concession of incentives is exceptional in nature and, unlike what happens with research materials, their purpose is to promote educational innovation and teaching excellence.

To improve this situation and make a better connection between teaching innovation and open access, it would be recommendable to include the development of OER in teaching evaluations, as a merit or scoring value. This recognition, along with the promotion of specific institutional policies, would avoid a situation wherein the creation of OER depends on the volunteerism of teaching staff.

A further focus of investigation has shed light on the type of teaching communities and educational resources deposited in Spanish IRs. The teaching communities began to appear in 2005 and were created, principally, during the period between 2008 and 2011. They are characterised by a low volume of available educational resources; with the exception of some repositories with large collections of exams, teaching guides and audiovisual materials.

With regard to the nature of educational resources in teaching communities, these can be characterised by a heterogeneity of formats and types; by the prominent use of licences which do not allow maximum openness and reuse; and by their description using Dublin Core metadata (more closely linked to predominant software in the IRs, DSpace, than to the most relevant metadata specification for this type of resource).

Therefore, resources with .pdf (text) and .mp4 (audio) formats and those with an unspecified type (known as "others") are most prevalent. A large volume of contents of a practical (exercises and problems) and theoretical (class notes) natu$r$, and an increase in audiovisual resources (class recordings, conferences, etc.) and documents with relation to teaching innovation have been observed. In any event, the scant empirical evidence does not allow for the establishment of a systematic type of available OER in Spanish IRs.

As we have discussed throughout the article, the authors become accustomed to using the most restrictive licences (which, on occasion, only permit making a copy of the resource). Furthermore, many of the educational resources cannot be reused due to issues that are legal (use of licences that do not allow the creation of derivatives), technical (proprietary or unmanageable formats) and practical in nature (use of general metadata that does not allow the viewing of educational specificities, nor, therefore, the retrieval of specific resources that may be of interest for reuse). In this vein and considering the implicit aspects of this type of resource, such as the educational purpose and reuse, only part of the total resources deposited could be considered as $100 \%$ reusable OERs.

The analysis of the current state of teaching collections and the proposal for stages of development, points to the fact that the majority of IRs are characterised by the dispersion and mix of resource types, user licences, metadata and deposit patterns (for example, the inclusion or exclusion of students' final projects). Few IRs contain resources created exclusively for teaching and learning and avail of appropriate licences for reuse. Therefore, this study shows that among institutions, a common procedure is not being followed nor is there a general awareness of what it means to create open educational resources. 
Therefore, we suggest that, in order to create OER with the maximum degree of openness and reuse, it is necessary to encourage collaborative working, among teaching staff and students and also among librarians in charge of IRs, as well as in teaching and learning support services. To that end, we recommend the creation of guides that include

- how to create materials with the exclusive purpose of teaching and learning;

- how to use open formats (or, at least, standardised formats);

- how to raise awareness about the use of licences that allow reuse; and finally,

- how to integrate specific and interoperable metadata.

This "snapshot" of the current situation regarding educational resources in Spanish universities should be complemented with further studies that examine the areas of interest identified and, at the same time, monitor the evolution of OER.

\section{References}

Abadal, Ernest; Ollé-Castellá, Candela; Abad-García, María-Francisca; Melero, Remedios (2013). "Políticas de acceso abierto a la ciencia en las universidades españolas". Revista española de documentación científica, v. 36, n. 2, e007. https://doi.org/10.3989/redc.2013.2.933

Aneca (2007). Programa Docentia. Programa de apoyo para la evaluación de la actividad docente del profesorado universitario.

http://www.aneca.es/content/download/13305/164819/file/DOCENTIA_nuevadoc_v1_final.pdf

Banzato, Monica (2012). "Barriers to teacher educators seeking, creating and sharing open educational resources: An empirical study of the use of OER in education in Italy". $15^{\text {th }}$ International conference on interactive collaborative learning (ICL), 26-28 September, Villach, Austria.

https://doi.org/10.1109/ICL.2012.6402105

Barrueco, José-Manuel; Andrés-Rodríguez, Aurelia; Rico-Castro, Pilar; Coslado-Bernabé, María-Ángeles (coords.) (2017). Guía para la evaluación de repositorios institucionales de investigación. Recyt; CRUE. https://www.recolecta.fecyt.es/sites/default/files/contenido/documentos/2017GuiaEvaluacionRecolectaFECYT.pdf

Barrueco, José-Manuel; De-Miguel-Estévez, Mercedes; González-Copeiro, Cristina; Rico-Castro, Pilar (coords.) (2014). Guía para la evaluación de repositorios institucionales de investigación. Fecyt; CRUE. https://www.rebiun.org/sites/default/files/Documentos/GT-REP/EvaluacionREP/GuiaEvaluacionRecolecta_2014.pdf

Belikov, Olga; Bodily, Robert (2016). "Incentives and barriers to OER adoption: A qualitative analysis of faculty perceptions". Open praxis, v. 8, n. 3, pp. 235-246.

https://www.learntechlib.org/p/173537

Bueno-De-la-Fuente, Gema (2010). Modelo de repositorio institucional de contenido educativo (RICE): la gestión de materiales digitales de docencia y aprendizaje en la biblioteca universitaria. Tesis doctoral. Madrid: Universidad Carlos III de Madrid.

http://hdl.handle.net/10016/9154

Bueno-De-la-Fuente, Gema; Hernández-Pérez, Tony (2011). "Estrategias para el éxito de los repositorios institucionales de contenido educativo en las bibliotecas digitales universitarias". BiD: Textos universitaris de biblioteconomia i documentació, n. 26. https://doi.org/10.1344/105.000001727

Butcher, Neil; Kanwar, Asha; Uvalic-Trumbic, Stamenka (2015). Guía básica de recursos educativos abiertos (REA). Paris: Unesco. ISBN 9789233000209 https://unesdoc.unesco.org/ark:/48223/pf0000232986

Casal-Reyes, Mabela; Borgoños-Martínez, María-Dolores; Casaldáliga, Anna; Gómez-Castaño, Javier; Guijarro, Concepción; Ortiz-Uceta, Eva; Pascual-del-Pobil-Valdenebro, Almudena; Rodríguez-Junco, Fernando; Terroba-Pascual, Isabel (2013). "El acceso abierto en las universidades españolas: estado de la cuestión y propuestas de mejora". Métodos de información, v. 4, n. 6, pp. 55-90.

https://doi.org/10.5557/iimei4-n6-055090

Cheung, Simon K. S. (2020) "A review of open access textbook platforms". In: Cheung, Simon K. S.; Li, Richard; Phusavat, Kongkiti; Paoprasert, Naraphorn; Kwok, Lam-For (eds.). Blended learning. Education in a smart learning environment. ICBL 2020. ISBN: 9783 030-51968 1 https://doi.org/10.1007/978-3-030-51968-1_10

España (2011a). “Ley 14/2011, de 1 de junio, de la ciencia, la tecnología y la innovación”. BOE, n. 131, 2 junio. https://www.boe.es/buscar/act.php?id=BOE-A-2011-9617

España (2011b). "Real decreto 99/2011, de 28 de enero, por el que se regulan las enseñanzas oficiales de doctorado". $B O E$, n. 35, 10 febrero.

https://www.boe.es/buscar/act.php?id=BOE-A-2011-2541 
Ferguson, Christine L. (2017). “Open educational resources and institutional repositories”. Serials review, v. 43, n. 1, pp. 34-38.

https://doi.org/10.1080/00987913.2016.1274219

Fernández-Pampillón-Cesteros, Ana-María; Domínguez-Romero, Elena; De-Armas-Ranero, Isabel (2013). "Análisis de la evolución de los repositorios institucionales de material educativo digital de las universidades". Relatec, v. 12, n. 2 , pp. 11-25.

https://relatec.unex.es/article/view/1165/791

García-Peñalvo, Francisco-José; Fidalgo-Blanco, Ángel; Sein-Echaluce, María-Luisa (2017). “Los moocs, un análisis desde una perspectiva de la innovación institucional universitaria”. La cuestión universitaria, n. 9, pp. 117-135.

https://dialnet.unirioja.es/servlet/articulo?codigo $=6279487$

Gómez-Castaño, Javier; París-Folch, María-Lidón; Aguilar-Lorente, Eduard; Martínez-Galindo, Francisco-Jesús; Barrueco, José-Manuel (2015). "Los repositorios institucionales de las universidades públicas valencianas: situación actual y retos para el futuro". En: XIV Workshop Rebiun de proyectos digitales y VI Jornadas OS-repositorios, 11-13 marzo, Universidad de Córdoba.

http://hdl.handle.net/10045/45785

Gómez-Ortega, Juan (dir.) (2017). Universitic 2017: Análisis de las TIC en las universidades españolas. Madrid: CRUE. ISBN: 9788469797594

https://tic.crue.org/wp-content/uploads/2018/03/UNIVERSITIC-2017.pdf

González-Teruel, Aurora (2005). Los estudios de necesidades y usos de la información: fundamentos y perspectivas actuales. Gijón: Trea, ISBN: 8497041666

Goodsett, Mandi; Loomis, Barbara; Miles, Marsha (2016). "Leading campus OER initiatives through library-faculty collaboration". College \& undergraduate libraries, v. 23, n. 3, pp. 335-342.

https://doi.org/10.1080/10691316.2016.1206328

Green, Cable (2017). “Open licensing and open education licensing policy”. In: Jhangiani, Rajiv S.; Biswas-Diener, Robert (eds.). Open: The philosophy and practices that are revolutionizing education and science. London: Ubiquity Press. pp. 29-41. ISBN: 9781911529019

https://doi.org/10.5334/bbc.c

Hilton, John; Wiley, David; Stein, Jared; Johnson, Aaron (2010). "The four 'R's of openness and ALMS analysis: frameworks for open educational resources". Open learning: The journal of open, distance and e-learning, v. 25, n. 1 , pp. 37-44.

https://doi.org/10.1080/02680510903482132

Johnson, Larry; Adams-Becker, Samantha; Cummins, Malcolm; Estrada, Victoria; Freeman, Alex; Ludgate, Holly (2013). NMC horizon report: 2013 higher education edition. Austin: The New Media Consortium. ISBN: 9780988376267 https://virtualeduca.org/documentos/2013/2013-horizon-report-he.pdf

Krippendorff, Klaus H. (2013). Content analysis: An introduction to its methodology. Los Angeles: SAGE. ISBN: 97814129 83150

López-Martín, Ramón (2018). “Cultura de innovación y calidad docente universitaria. Aportaciones para repensar el futuro". En: Edunovatic 2017. 2nd virtual international conference on education, innovation and ict, 12-14 December, pp. 404-411.

https://dialnet.unirioja.es/servlet/articulo?codigo=7013396

Martí, Ramon; Gisbert, Mercè; Larraz, Virginia (2018). “Ecosistemas tecnológicos de aprendizaje y gestión educativa. Características estratégicas para un diseño eficiente". Edutec. Revista electrónica de tecnología educativa, n. 64, pp. 1-17. https://doi.org/10.21556/edutec.2018.64.1025

McGreal, Rory; Miao, Fengchun; Mishra, Sanjaya (2016). “Introduction”. En: Miao, Fengchun; Mishra, Sanjaya; McGreal, Rory. Open educational resources: policy, costs, transformation. Paris: Unesco; Commonwealth of Learning, pp. 1-12. ISBN: 9789231001482

https://unesdoc.unesco.org/ark:/48223/pf0000244365

Melero, Remedios (2008). "El paisaje de los repositorios institucionales open access en España”. BiD: Textos universitaris de biblioteconomia i documentació, n. 20.

http://bid.ub.edu/pdf/20meler4.pdf

Melero, Remedios; Abadal, Ernest; Abad-García, María-Francisca; Rodríguez-Gairín, Josep-Manuel (2009). Situación de los repositorios institucionales en España: informe 2009

http://hdl.handle.net/10261/11354 
Morales-Morgado, Erla-Mariela; Campos-Ortuño, Rosalynn-Argelia; Ferreras-Fernández, Tránsito (2019). “Guía de metadatos educativos para agregar recursos educativos abiertos (REA) en repositorios basados en DSpace". En: $18^{a}$ Workshop de Rebiun de proyectos digitales y $8^{a}$ Jornadas de Os-repositorios, 25-27 septiembre, Universidad de León. https://buleria.unileon.es/handle/10612/11186

Ochoa, Xavier (2011). "Learnometrics: Metrics for learning objects”. In: 1st International conference on learning analytics and knowledge, pp. 1-8.

https://doi.org/10.1145/2090116.2090117

Rebiun (2007). Encuesta sobre la situación de los repositorios de materiales didácticos y objetos de aprendizaje en las universidades españolas. Informe Final II Plan estratégico 2007-2011.

Rebiun (2019). Recursos educativos abiertos: estado de la cuestión y pautas para su impulso en las universidades españolas. Madrid: CRUE, Rebiun, Línea 3 ( $3^{\text {er }}$ P.E.). Grupo de Repositorios. https://rebiun.xercode.es/xmlui/bitstream/handle/20.500.11967/243/Informe_REBIUN_A6_20190116_1.pdf

Rodés-Paragarino, Virginia; Gewerc-Barujel, Adriana; Llamas-Nistal, Martín (2015). "Uso de repositorios de recursos educativos digitales. Revisión de estado del arte". VAEP-RITA, v. 3, n. 2, pp. 78-84.

http://rita.det.uvigo.es/VAEPRITA/index.php?content=Num_Pub\&idiom=Es\&visualiza=1\&volumen=3\&numero=2\&orden=asC

Romero-Peláez, Audrey; Segarra-Faggioni, Verónica; Piedra, Nelson; Tovar, Edmundo (2019). “A proposal of quality assessment of OER based on emergent technology". In: IEEE Global engineering education conference, Educon, pp. 11141119.

https://doi.org/10.1109/EDUCON.2019.8725067

Santos-Hermosa, Gema (2018). "The role of academic libraries in MOOCs”. In: Ubachs, George; Konings, Lizzie (eds.). The envisioning report for empowering universities. Maastricht: EADTU, pp. 48-51.

https://tinyurl.com/envisioning-report

Santos-Hermosa, Gema; Ferran-Ferrer, Núria; Abadal, Ernest (2012). "Recursos educativos abiertos: repositorios y uso". El profesional de la información, v. 21, n. 2, pp. 136-145.

https://doi.org/10.3145/epi.2012.mar.03

Santos-Hermosa, Gema; Ferran-Ferrer, Núria; Abadal, Ernest (2017). "Repositories of open educational resources: An assessment of reuse and educational aspects". International review of research in open and distributed learning, v. 18, n. 5, pp. 84-120.

https://doi.org/10.19173/irrodl.v18i5.3063

Serrano-Vicente, Rocío; Melero, Remedios; Abadal, Ernest (2018). "Evaluation of Spanish institutional repositories based on criteria related to technology, procedures, content, marketing and personnel". Data technologies and applications, v. 52, n. 3, pp. 384-404.

https://doi.org/10.1108/DTA-10-2017-0074

Tovar, Edmundo (2013). Aplicación de tecnologías web emergentes para el estudio del impacto de repositorios OpenCourseWare españoles y latinoamericanos en la Educación Superior. Madrid: Universidad Politécnica de Madrid. ISBN: 9788469572252

Turró, Carlos; Mengod, Raúl; Morales, Juan-Carlos; Busquets, Jaime (2016). "Video is key for flipped learning: An experience at Universitat Politècnica de Valencia". In: Proceedings of the Workshop on Smart Environments and Analytics in Video-Based Learning (SE@VBL).

http://ceur-ws.org/Vol-1579/paper4.pdf

Unesco (2012). Paris OER declaration.

https://en.unesco.org/oer/paris-declaration

Unesco (2019). Draft recommendation on open educational resources. Paris: General conference, $40^{\text {th }}$ session.

https://unesdoc.unesco.org/ark:/48223/pf0000370936

Universidad de Málaga (2019). Plan propio integral de docencia.

https://www.uma.es/plan-propio-integral-de-docencia

Universitat de Lleida (2016). Manual d'avaluació docent de professorat.

http://www.udl.cat/export/sites/universitat-Ileida/ca/udl/norma/.galleries/docs/Personal_academic/ManualAvaluacio-Docent-Professorat-CG-25-doctubre-del-2016.pdf

Universitat de València (2019). Manual para la evaluación de la actividad docente del profesorado. Programa Docentia. https://www.uv.es/uq/docs/c/Docentia UV.pdf

Wiley, David (2019). Legal requirements and restrictions make open content and OER less open.

http://opencontent.org/definition 